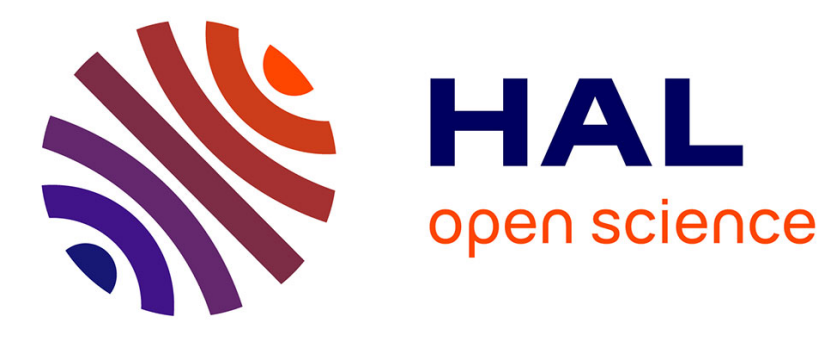

\title{
New accurate compression data for $\gamma-\mathrm{FeSiO}$
}

Nestola Fabrizio, Boffa Ballaran Tiziana, Koch-Müller Monika, Balic-Zunic Tonci, Taran Michael, Olsen Lars, Princivalle Francesco, Secco Luciano, Lundegaard Lars

\section{- To cite this version:}

Nestola Fabrizio, Boffa Ballaran Tiziana, Koch-Müller Monika, Balic-Zunic Tonci, Taran Michael, et al. New accurate compression data for $\gamma$-FeSiO. Physics of the Earth and Planetary Interiors, 2010, 183 (3-4), pp.421. 10.1016/j.pepi.2010.09.007 . hal-00702316

\section{HAL Id: hal-00702316 https://hal.science/hal-00702316}

Submitted on 30 May 2012

HAL is a multi-disciplinary open access archive for the deposit and dissemination of scientific research documents, whether they are published or not. The documents may come from teaching and research institutions in France or abroad, or from public or private research centers.
L'archive ouverte pluridisciplinaire HAL, est destinée au dépôt et à la diffusion de documents scientifiques de niveau recherche, publiés ou non, émanant des établissements d'enseignement et de recherche français ou étrangers, des laboratoires publics ou privés. 


\section{Accepted Manuscript}

Title: New accurate compression data for $\gamma-\mathrm{Fe}_{2} \mathrm{SiO}_{4}$

Authors: Nestola Fabrizio, Boffa Ballaran Tiziana, Koch-Müller Monika, Balic-Zunic Tonci, Taran Michael, Olsen Lars, Princivalle Francesco, Secco Luciano, Lundegaard Lars

PII: S0031-9201(10)00189-5

DOI:

Reference: doi:10.1016/j.pepi.2010.09.007

To appear in: $\quad$ Physics of the Earth and Planetary Interiors

Received date: $\quad$ 29-11-2009

Revised date: $\quad 19-8-2010$

Accepted date: $\quad$ 10-9-2010

Please cite this article as: Fabrizio, N., Tiziana, B.B., Monika, K.-M., Tonci, B.Z., Michael, T., Lars, O., Francesco, P., Luciano, S., Lars, L., New accurate compression data for $\gamma-\mathrm{Fe}_{2} \mathrm{SiO}_{4}$, Physics of the Earth and Planetary Interiors (2010), doi:10.1016/j.pepi.2010.09.007

This is a PDF file of an unedited manuscript that has been accepted for publication. As a service to our customers we are providing this early version of the manuscript. The manuscript will undergo copyediting, typesetting, and review of the resulting proof before it is published in its final form. Please note that during the production process errors may be discovered which could affect the content, and all legal disclaimers that apply to the journal pertain. 


\title{
New accurate compression data for $\gamma-\mathrm{Fe}_{2} \mathrm{SiO}_{4}$.
}

Nestola Fabrizio ${ }^{1}$, Boffa Ballaran Tiziana ${ }^{2}$, Koch-Müller Monika ${ }^{3}$, Balic-Zunic Tonci ${ }^{4}$, Taran Michael $^{5}$, Olsen Lars ${ }^{4}$, Princivalle Francesco ${ }^{6}$, Secco Luciano $^{1}$, Lundegaard Lars ${ }^{7}$

\author{
${ }^{1}$ Dipartimento di Geoscienze, Università di Padova, Via Giotto 1, I-35137 Padova (Italy) \\ ${ }^{2}$ Bayerisches Geoinstitut, University of Bayreuth, Universitaetsrasse 37, D-95447 Bayreuth (Germany) \\ ${ }^{3}$ Deutsch GeoForschungsZentrum Potsdam, Dept. 4, D-14473 Potsdam (Germany) \\ ${ }^{4}$ Department of Geography and Geology, University of Copenhagen, Øster Voldgade 10, DK-1350 Copenhagen K, \\ Denmark \\ ${ }^{5}$ Institute of Geochemistry, Mineralogy and Ore Formation, National Academy of Science of Ukraine, Palladin Ave., \\ 34, 03680 Kyiv-142 (Ukraine) \\ ${ }^{6}$ Dipartimento di Scienze della Terra, Università di Trieste, Via Weiss 8, I-34127 Trieste (Italy) \\ ${ }^{7}$ Haldor Topsoe, Nymoellevej 55, 2800 Kgs. Lyngby, Denmark
}

\begin{abstract}
The equation of state for $\gamma-\mathrm{Fe}_{2} \mathrm{SiO}_{4}$ was determined by single-crystal X-ray diffraction up to 10.2 $\mathrm{GPa}$ at room temperature. The pressure - volume data, measured at 10 different pressures, do not show any evidence of a phase transformation and were fit by a third-order Birch-Murnaghan equation of state. The following coefficients were refined simultaneously: $V_{0}=559.44(6) \AA^{3}, K_{\mathrm{T} 0}=$ 187.3(1.7) $\mathrm{GPa}$, and $K^{\prime}=5.5(4)$. This result implies that the $\mathrm{Mg} / \mathrm{Fe}$ substitution along the $\gamma$-Fo-Fa join does not significantly affect the bulk modulus. The sample shows higher $K^{\prime}$ than other compositions along the Fo-Fa join, which generally have $K^{\prime} \sim 4$. Based on our results we can calculate the sound bulk velocity of $\gamma-\mathrm{Fe}_{2} \mathrm{SiO}_{4}$ up to the pressures of the Transition Zone. Due to the larger $K^{\prime}$ of $\gamma-\mathrm{Fe}_{2} \mathrm{SiO}_{4}$, the difference in bulk sound velocity between the two end-members decreases with increasing pressure.
\end{abstract}

Keywords: $\gamma$ - $\mathrm{Fe}_{2} \mathrm{SiO}_{4}$; elastic properties; single-crystal; X-ray diffraction

\section{Introduction}

Ringwoodite ( $\gamma$-olivine with spinel-like structure and $[\mathrm{Mg}, \mathrm{Fe}]_{2} \mathrm{SiO}_{4}$ composition) is among the most investigated phases in Earth sciences (e.g. Weidner et al. 1984; Duffy and Anderson 1989; Ridgen 
and Jackson 1991; Hazen et al. 1993; Kiefer et al. 1997; Sinogeikin et al. 1997; Matsui 1999; Jackson et al. 2000; Frost 2003; Li 2003; Higo et al. 2006) due to its abundance in the Transition Zone of the Earth's mantle (about 55\%, Anderson 1995) and to the characteristic polymorphic transformations which are probable causes of seismic discontinuities at depths of $410 \mathrm{~km}(\alpha$-olivine to $\beta$-olivine transformation) and $525 \mathrm{~km}$ ( $\beta$-olivine to $\gamma$-olivine transformation, see Frost 2003 and references therein). Moreover, at the transition from the upper to the lower mantle, ringwoodite breaks down to ferropericlase $+\mathrm{Mg}$-perovskite, which should be the primary cause of the major seismic discontinuity at $660 \mathrm{~km}$ depth (e.g. Chudinovskikh and Boehler 2001).

In the last decade several experimental and computational works have been mainly focused on the effect that water substitution has on the thermodynamic properties of ringwoodite. It has been shown that $\mathrm{H}_{2} \mathrm{O}$ can be hosted by the ringwoodite structure up to more than 2 weight \% (e.g. Kohlstedt et al. 1996; Smyth et al. 2003; Demouchy et al. 2005; Smyth 2006) and that water incorporation has a strong effect on the elastic properties of ringwoodite with a reduction of the bulk modulus that can reach 6-7\% (e.g. Inoue et al. 1998; Wang et al. 2003; Smyth et al. 2004; Manghnani et al. 2005; Jacobsen et al. 2004; Jacobsen and Smyth 2006). Less constrained is the effect of Fe substitution on the elastic properties of ringwoodite. A recent phase diagram calculated at $1400^{\circ} \mathrm{C}$ for the $\mathrm{Mg}_{2} \mathrm{SiO}_{4}-\mathrm{Fe}_{2} \mathrm{SiO}_{4}$ binary join defines the polymorphic phase relations as a function of pressure (Frost 2003). For $\mathrm{Mg} /(\mathrm{Mg}+\mathrm{Fe})>0.4 \alpha$-olivine directly transforms to ringwoodite with a complete transformation occurring at about $13 \mathrm{GPa}$. The transformation pressure decreases with increasing Fe content and reaches $11 \mathrm{GPa}$ for $\mathrm{Mg} /(\mathrm{Mg}+\mathrm{Fe}) \sim 0.6$. Thermodynamic data (e.g. bulk modulus, thermal expansion, molar volume) for iron-rich ringwoodites are, however, scarce and show some discrepancies. For instance the experimental work by Ridgen and Jackson (1991) reported for pure $\gamma-\mathrm{Fe}_{2} \mathrm{SiO}_{4}$ a value of bulk modulus $K_{\mathrm{T} 0}=201 \mathrm{GPa}$ and a value of its first pressure derivative $K^{\prime}=5.59$. Hazen (1993) demonstrated the strong effect of $\mathrm{Fe}^{2+}$ on the elastic properties of Mg-ringwoodite with an increase in bulk modulus for pure $\gamma-\mathrm{Fe}_{2} \mathrm{SiO}_{4}$ by about $13 \%$, 
going from $184 \mathrm{GPa}$ of $\mathrm{Mg}_{2} \mathrm{SiO}_{4}$ to $207 \mathrm{GPa}$ of $\mathrm{Fe}_{2} \mathrm{SiO}_{4}$ with $K^{\prime}$ ranging from values slighter greater than 4 for Mg-end member to values lower than 4 for the Fe-rich samples. More recent studies proposed various relationships to determine the change in $K_{\mathrm{T} 0}$ as a function of $\mathrm{Fe}^{2+}$ in ringwoodite: $K_{\mathrm{T} 0}=184(2)+36(5) \times \mathrm{X}_{\mathrm{Fe}}(\mathrm{GPa})\left(\right.$ Sinogeikin et al. 1998); $K_{\mathrm{T} 0}=184(2)+16(1) \times \mathrm{X}_{\mathrm{Fe}}(\mathrm{GPa})(\mathrm{Higo}$ et al. 2006). The recent work by Higo et al. (2006) also proposed that the first pressure derivative $K^{\prime}$ remains virtually constant along the join at values of 4-4.5. Liu et al. (2008) studied a $\gamma-\mathrm{Fe}_{2} \mathrm{SiO}_{4}$ sample finding a significant increase in the adiabatic bulk modulus $\left(K_{\mathrm{s}}=204.5 \mathrm{GPa}\right)$ with respect to $\mathrm{Mg}_{2} \mathrm{SiO}_{4}$ composition. However, Matsui et al. (2006), studying a ringwoodite sample with composition $\mathrm{Mg}_{1.80} \mathrm{Fe}_{0.20} \mathrm{SiO}_{4}$, found negligible differences in bulk modulus with respect to the pure $\mathrm{Mg}_{2} \mathrm{SiO}_{4}$ end-member. The most recent study on ringwoodite under high-pressure conditions is from Ganskow et al. (2010) who investigated two hydrous samples with composition $\mathrm{Mg}_{0.97} \mathrm{Fe}_{1.00} \mathrm{Si}_{0.98} \mathrm{H}_{0.14} \mathrm{O}_{4}$ and $\mathrm{Mg}_{1.23} \mathrm{Fe}_{0.77} \mathrm{Si}_{0.98} \mathrm{H}_{0.07} \mathrm{O}_{4}$. For such samples the authors found $V_{0}=$ 543.32(7) $\AA^{3}, K_{\mathrm{T} 0}=186.5(9) \mathrm{GPa}$ and $V_{0}=539.01(5) \AA^{3}, K_{\mathrm{T} 0}=184.1(7) \mathrm{GPa}$, respectively, with a $K^{\prime}$ close to 4 for both the samples investigated.

It appears, therefore, that while for the end-member $\mathrm{Mg}_{2} \mathrm{SiO}_{4}$ composition there is a general agreement on an average value of bulk modulus of $184 \mathrm{GPa}$, for the Fe-richer samples the data show a larger degree of scatter going from 185 to $209 \mathrm{GPa}$ and $K^{\prime}$ from 4.1 to 5.6. In this work we have conducted high-pressure in situ measurements on a single-crystal of $\gamma$ - $\mathrm{Fe}_{2} \mathrm{SiO}_{4}$ up to $10.2 \mathrm{GPa}$ by X-ray diffraction in a diamond anvil cell to determine accurate values of the unit-cell lattice parameters at different pressures. From these data we calculate precise values of both bulk modulus and its first pressure derivative to compare with those of Mg-richer ringwoodites with the final aim of clarifying the effect of iron on the compressibility of ringwoodite spinel.

\subsection{Experimental procedure}

The sample studied in this work is a fragment of the sample MA75 earlier studied by Taran et al. (2009) synthesized at $7 \mathrm{GPa}$ and $1100^{\circ} \mathrm{C}$ for 24 hours in a multi-anvil apparatus. The sample has 
some impurity of $\mathrm{Mg}$ (0.03 a.p.f.u.) and $\mathrm{Fe}^{3+}$ (0.10 a.p.f.u). The synthesis was performed under hydrous conditions (about 3 weight $\%$ of $\mathrm{H}_{2} \mathrm{O}$ ) to obtain crystals of high quality. The low temperature used during the syntheses did not cause the entrance of much water in the crystal structure of $\gamma-\mathrm{Fe}_{2} \mathrm{SiO}_{4}$, in fact, the water content for the sample Ma75 studied in the work lies between 0.1 (IR spectroscopy, Taran et al. 2009) and 0.2 weight \% (SIMS determination, KochMüller personal communication).

The single crystal for the high-pressure study was selected based on the lack of twinning (checked by preliminary single-crystal analysis) and on sharpness of diffraction profiles (typical half-widths of reflections were between $0.05^{\circ}$ and $0.06^{\circ}$ in $\omega$ ). The size of the chosen crystal was $130 \times 80 \times 40$ $\mu \mathrm{m}^{3}$. The sample was loaded in a BGI-type diamond-anvil cell, using a steel gasket (T301) preindented to $80 \mu \mathrm{m}$ with a hole diameter of $250 \mu \mathrm{m}$. The diameters of the diamond culets were $600 \mu \mathrm{m}$. A 4:1 mixture of methanol:ethanol was used as pressure transmitting medium (such mixture transmits the pressure hydrostatically throughout the entire range of pressure investigated in this work as demonstrated by Angel et al. 2007 and confirmed by the constancy of the obtained diffraction profiles). A quartz crystal, used as an internal diffraction pressure standard (Angel et al. 1997), was also loaded into the pressure cell. Unit-cell parameters were determined by X-ray diffraction experiments at the Bayerisches Geoinstitut (Bayreuth) on a HUBER four-circle diffractometer operating at $50 \mathrm{kV}$ and $40 \mathrm{~mA}$, centering not less than 14 reflections for each highpressure experiment, in the $2 \theta$ range between $10^{\circ}$ and $30^{\circ}$. Full details of the instrument and the peak-centering algorithms are provided by Angel et al. (2000). During the centering procedure the effects of crystal offsets and diffractometer aberrations were eliminated from refined peak positions by the eight-position centering method of King and Finger (1979). Unconstrained unit-cell parameters, obtained by vector least-squares (Ralph and Finger 1982), were measured at 10 different pressures from room pressure up to about 10.2 GPa. The unit-cell parameters were found 
to be similar, within one estimated standard deviation, to the symmetry-constrained ones. The resulting unit-cell volumes and are reported in Table 1.

\section{Results}

\subsection{Equation of state: isothermal bulk modulus and first pressure derivative.}

The unit-cell volume of the $\gamma-\mathrm{Fe}_{2} \mathrm{SiO}_{4}$ sample studied in this work is shown as a function of pressure in Figure 1. No evidence of a phase transition is observed up to the maximum pressure reached. The unit-cell volume undergoes a reduction of about $2.1 \%$ at $10.2 \mathrm{GPa}$ indicating a marked stiffening of the structure with respect to upper mantle silicates such as olivine and pyroxene. The pressure-volume data reported in Table 1 were fitted to a third-order Birch-Murnaghan equation of state (Birch 1947, BM3-EoS) using the EoS-FIT5.2 program (Angel 2000). The unit-cell volume, $V_{0}$, the bulk modulus, $K_{\mathrm{T} 0}$, and its first pressure derivative, $K^{\prime}$, were refined simultaneously and the following EoS coefficients were obtained: $V_{0}=559.44(6) \AA^{3}, K_{\mathrm{T} 0}=187.3(1.7) \mathrm{GPa}, K^{\prime}=5.5(4)$. The fitting procedure shows very low values of $\Delta \mathrm{P}_{\max }$ (this parameter is defined as $\left|\mathrm{P}_{\text {obs }}-\mathrm{P}_{\text {calc }}\right|_{\max }$ and in our experiments it reaches only $0.038 \mathrm{GPa}$ ) and $\chi^{2}(0.96)$ close to 1 (Angel 2000). Moreover, the $F_{\mathrm{E}}-f_{\mathrm{E}}$ plot (based on the eulerian strain $f_{\mathrm{E}}=\left[\left(V_{0} / V\right)^{2 / 3}-1\right] / 2$ and the normalized stress $F_{\mathrm{E}}=$ $\left.P /\left[3 f_{\mathrm{E}}\left(1+2 f_{\mathrm{E}}\right)^{5 / 2}\right]\right)$ showed in Figure 2 indicates that the BM3-EoS well describes well our pressure - volume data (Angel 2000) and the positive slope confirms that $K^{\prime}$ is greater than 4 . In Figure 2 the intercepts on the $F_{\mathrm{E}}$ axis gives a value of bulk modulus of $188.7(9) \mathrm{GPa}$, while the slope (slope $=3$ $\left.K_{\mathrm{T} 0}\left(K^{\prime}-4\right) / 2\right)$ provides a value of $K^{\prime}$ of 5.3(3). The differences between the values obtained by the pressure - volume least-squares refinement using the BM3 EoS and the $F_{\mathrm{E}-} f_{\mathrm{E}}$ plot tool are within standard deviations, again indicating high accuracy of the data.

2.2. Relationships among isothermal bulk modulus, its first pressure derivative and pressure. 
The correlation between the bulk modulus and its first pressure derivative is close to $100 \%$ (e.g. Angel 2000) and therefore, to determine $K^{\prime}$, it is crucial to obtain a very reliable bulk modulus. This correlation must be also taken into account when a set of EoS parameters are determined by a leastsquares refinement (as done for our $P-V$ data using EosFit 5.2 software), which considers the refined values of $K_{\mathrm{T} 0}$ and $K^{\prime}$ as independent. Such procedure, in fact, could underestimate the errors in the determination of $K_{\mathrm{T} 0}$ and $K^{\prime}$. A useful tool to better represent more realistic errors in the determination of $K_{\mathrm{T} 0}$ and $K^{\prime}$ is the construction of a confidence ellipse (Angel 2000), which takes into account the correlation between the two EoS parameters. The confidence ellipse for our sample is reported in Figure 3. The plot not only shows the strong negative correlation between $K_{\mathrm{T} 0}$ and $K^{\prime}$ but at the same time provides a better visualisation of their uncertainties. For example the error on $K_{\mathrm{T} 0}$ calculated using the ellipse is $2.7 \mathrm{GPa}$ instead of $1.7 \mathrm{GPa}$ from the assumption of independent parameters. For $K^{\prime}$ the uncertainty increases from 0.4 to 0.5 .

The variation of $K_{\mathrm{T}}$ with pressure up to $20 \mathrm{GPa}$ is shown in Figure 4 . As expected, $K_{\mathrm{T}}$ increases with increasing pressure (it has been recently reported for some feldspars, Benusa et al. [2005]; Nestola et al. [2008], and for antigorite, Nestola et al. [2010], an anomalous behaviour of $K_{\mathrm{T}}$ with pressure showing an unexpected softening) and, due to the $K^{\prime}$ value larger than 4 , the rate at which the bulk modulus increases is larger than for $\mathrm{Mg}_{2} \mathrm{SiO}_{4}$ ringwoodite.

\section{Discussion}

\subsection{Bulk modulus, first pressure derivative and composition.}

The value of the bulk modulus obtained in this study is practically the same within the uncertainties of that determined using different techniques for anhydrous $\mathrm{Mg}_{2} \mathrm{SiO}_{4}$ ringwoodite (Hazen 1993; Jackson et al. 2000; $\mathrm{Li}$ 2003). The major difference between the two end-members is the inconsistency of $K^{\prime}$, which is 5.5 for our $\gamma-\mathrm{Fe}_{2} \mathrm{SiO}_{4}$ sample and 4 for $\gamma-\mathrm{Mg}_{2} \mathrm{SiO}_{4}$. Our result of $K^{\prime}=$ 5.5 is in agreement with that reported for a $\gamma-\mathrm{Fe}_{2} \mathrm{SiO}_{4}$ by Ridgen and Jackson (1991). As a 
consequence of the larger value of $K^{\prime}, \gamma-\mathrm{Fe}_{2} \mathrm{SiO}_{4}$ will become stiffer than the $\mathrm{Mg}$-end-member at high pressures. The bulk modulus found in this study is slightly smaller than those reported in the literature (Rigden and Jackson 1991; Hazen 2003) and would imply that $\mathrm{Mg} / \mathrm{Fe}$ substitution has little effect on the elastic properties of ringwoodite. It has been shown that both water incorporation in ringwoodite (Inoue et al. 1998; Wang et al. 2003; Manghnani et al. 2003; Jacobsen et al. 2004; Jacobsen and Smyth 2006) as well as the presence of vacancies in the spinel structure (Nestola et al. 2009) decreases the bulk modulus with respect to anhydrous and stoichiometric samples. The $\gamma$ $\mathrm{Fe}_{2} \mathrm{SiO}_{4}$ sample investigated in this study has marginal water content (less than $0.2 \%$ ), it is therefore unlikely that this quantity would visibly affect its bulk modulus. The presence of 0.1 apfu of $\mathrm{Fe}^{3+}$ is, however, slightly more significant. Taran et al. (2009) observed by means of Mössbauer spectroscopy that $\mathrm{Fe}^{3+}$ appears to occupy the octahedral sites in the ringwoodite structure, but the authors could not rule out that some $\mathrm{Fe}^{3+}$ occupying the tetrahedral site. Structure refinement recently performed using single-crystal X-ray diffraction on a fragment of the same crystal studied in this work indicates a nearly equal distribution of $\mathrm{Fe}^{3+}$ over both the octahedral and tetrahedral sites (Princivalle et al., unpublished data). If all $\mathrm{Fe}^{3+}$ occupies the octahedral sites, we should expect a non-negligible number of vacancies due to the oxidation of Fe which is not balanced by the protonation of oxygens (McCammon et al. 2004) given the insignificant amount of water in our sample. This would result in a slightly more compressible structure than that of stoichiometric ringwoodite. If $\mathrm{Fe}^{3+}$ is equally distributed among octahedral and tetrahedral sites, as suggested by Taran et al. (2009) and the recent refinements, then its effect on the compressibility of ringwoodite is less obvious. The tetrahedral site occupied by $\mathrm{Fe}^{3+}$ are likely softer than those occupied by $\mathrm{Si}$, however we can also expect the octahedral sites with trivalent iron being stiffer than those with $\mathrm{Fe}^{2+}$. Moreover, the coupled substitution results in only 0.05 apfu of $\mathrm{Fe}^{3+}$ in each site, which may be too little to have an observable effect on the compressibility of ringwoodite.

\subsection{Bulk sound velocity at Transition Zone pressures}


Using the EoS parameters calculated in this work we can calculate the bulk sound velocity $V_{\Phi}\left(V_{\Phi}\right.$ $=\sqrt{K_{\mathrm{T}} / \rho}$ ) for $\gamma-\mathrm{Fe}_{2} \mathrm{SiO}_{4}$. The same calculation has been performed for $\mathrm{Mg}_{2} \mathrm{SiO}_{4}$ ringwoodite $\left(\mathrm{Fo}_{100} \mathrm{Fa}_{0}\right)$ using the unit-cell volume provided by Hazen (1993) and the bulk modulus provided by Sinogeikin et al. (1998) with $K^{\prime}=4$. In a recent work on two intermediate hydrous $\mathrm{Mg}_{0.97} \mathrm{Fe}_{1.00} \mathrm{Si}_{0.98} \mathrm{H}_{0.14} \mathrm{O}_{4}$ (ideal $\mathrm{Fo}_{50} \mathrm{Fa}_{50}$ ) and $\mathrm{Mg}_{1.23} \mathrm{Fe}_{0.77} \mathrm{Si}_{0.98} \mathrm{H}_{0.07} \mathrm{O}_{4}$ (ideal $\mathrm{Fo}_{62} \mathrm{Fa}_{38}$ ) compositions (Ganskow et al. 2010), the ringwoodite samples were investigated in the same laboratory and with the same diamond cells used in the present work. The authors found a $K_{\mathrm{T} 0}=186.5(9) \mathrm{GPa}$ and 184.1(7) GPa, respectively, with a $K^{\prime}$ close to 4 for both the samples. Also for these two samples the bulk sounds velocities have been calculated down to the Transition Zone (Figure 5). Given the similar bulk moduli of all samples independent of iron content, the bulk sound velocity decreases with increasing the molar fraction of Fa. At room pressure (Fig. 5) we obtain:

$$
\mathrm{V}_{\Phi}(\mathrm{Km} / \mathrm{s})=7.16(4) \mathrm{km} / \mathrm{s}-0.96(7) \times\left[\mathrm{X}_{\mathrm{Fa}}\right]
$$

At pressures typical of the Transition Zone (e.g. $540 \mathrm{~km}, 18 \mathrm{GPa}$ ), the difference in the bulk sound velocity between the two end-members is much smaller (Fig. 5) due to the larger $K^{\prime}$ of $\gamma-\mathrm{Fe}_{2} \mathrm{SiO}_{4}$. Because studies of ringwoodite with various Fe and water contents (Sinogeikin et al. 2001; Higo et al. 2006; Ganskow et al. 2010) consistently yield $K^{\prime} \sim 4$, similar to the value for the $\mathrm{Mg}_{2} \mathrm{SiO}_{4}$ endmembers, it appears that a different compression mechanism may be responsible for the stiffer behaviour of $\gamma-\mathrm{Fe}_{2} \mathrm{SiO}_{4}$ at high-pressures. It is still an open question whether Fe-rich (i.e. $\mathrm{Fa}>50$ ) also have a $K^{\prime}$ larger than 4 .

The only available data on the variation of $K_{\mathrm{T} 0}$ as a function of temperature are from studies of $\mathrm{Mg}_{2} \mathrm{SiO}_{4}$ end-member (Meng et al. 1993) and $\mathrm{Mg}_{1.91} \mathrm{Fe}_{0.09} \mathrm{SiO}_{4}$ (Sinogeikin et al. 2003) ringwoodites. For these two samples the authors obtain an almost identical value $\partial K_{\mathrm{T}} / \partial T=-$ 0.027/0.028 GPa/K. For a temperature of $2100 \mathrm{~K}$ typical of the Transition Zone $K_{\mathrm{T}}$ would assume a value of about $135 \mathrm{GPa}$ at least for Fe-poor compositions. The only available data of $\partial K_{\mathrm{T}} / \partial T$ obtained for richer-Fe compositions have been carried out on the $\beta$-olivine phase with composition 
$\mathrm{Mg}_{1.68} \mathrm{Fe}_{0.32} \mathrm{SiO}_{4}$ (Fei et al. 1992). We conclude that $\partial K_{\mathrm{T}} / \partial T$ does not show any dependence on $\mathrm{Fe}$ content. A comparison between $\beta$-olivine and $\gamma$-olivine is not trivial and the same statement reported about the effect of $\mathrm{Fe}$ on $\partial K_{\mathrm{T}} / \partial T$ for $\gamma-\mathrm{Fe}_{2} \mathrm{SiO}_{4}$ cannot be simply applicable. In order to fully determine the thermo-elastic behaviour of ringwoodite spinel as a function of $\mathrm{Fe}$ content further works therefore are still necessary.

\section{Acknowledgments}

F.N. thanks the MIUR PRIN 2006047943 for financial support. Two anonymous referees and Chris Holl are thanked for their help in improving the manuscript.

\section{References}

Anderson, O.L., 1995. Equations of state of solids for geophysics and ceramic sciences. Oxford University Press, Oxford, p. 34.

Angel, R.J., 2000. Equations of State. Rev. Min. Geochem. 41, 35-39.

Angel, R.J., Allan, D.R., Miletich, R., Finger, L.W., 1997. The use of quartz as an internal pressure standard in high pressure crystallography. J. Appl. Cryst., 30, 461-466.

Angel, R.J., Downs, R.T., Finger, L.W., 2000. High-temperature-high-pressure diffractometry. Rev. Min. Geochem. 62, 559-596.

Angel, R.J., Bujak, M., Zhao, J., Gatta, G.D., Jacobsen, S.D., 2007. Effective hydrostatic limits of pressure media for high-pressure crystallographic studies. J. Appl. Crystall. 40, 26-32.

Benusa, M.D., Angel, R.J., Ross, N.L., 2005. Compression of albite, $\mathrm{NaAlSi}_{3} \mathrm{O}_{8}$. Am. Mineral. 90, 115-1120.

Birch, F., 1947. Finite elastic strain of cubic crystals. Phys. Rev. 71, 809-824.

Chudinovskikh, L., Boehler, R., 2001. High-pressure polymorphs of olivine and the $660-\mathrm{km}$ seismic discontinuity. Nature, 411, 574-577.

Demouchy,S., Deloule, E., Frost, D.J., Keppler, H., 2005. Pressure and temperature-dependence of water solubility in Fe-free wadsleyite. Am. Mineral., 90, 1084-1091.

Duffy, T.S., Anderson, D.L., 1989. Seismic velocities in mantle minerals and the mineralogy of the upper mantle. J. Geophys. Res. 94, 1895-1912.

Frost, D.J., 2003, The structure and sharpness of $(\mathrm{Mg}, \mathrm{Fe})_{2} \mathrm{SiO}_{4}$ phase transformations in the Transition Zone. Earth Planet. Sci. Lett. 216, 313-328. 
Ganskow, G., Boffa Ballaran, T., Langenhorst, F., 2010, Effect of iron on the compressibility of hydrous ringwoodite. Am. Mineral. 95, 747-753.

Hazen, R.M., 1993. Comparative compressibilities of silicate spinels: anomalous behavior of $(\mathrm{Mg}, \mathrm{Fe})_{2} \mathrm{SiO}_{4}$. Science 259, 206-209.

Hazen, R.M, Downs, R.T., Finger, L.W., Ko, J., 1993. Crystal chemistry of ferromagnesian silicate spinels: evidence for Mg-Si disorder. Am. Mineral. 78, 1320-1323.

Higo, Y., Inoue, T., Li, B., Irifune, T., Liebermann, R.C., 2006. The effect of iron on the elastic properties of ringwoodite at high pressure. Phys. Earth Planet. Inter. 159, 276-285.

Inoue, T., Weidner, D.J., Northrup, P.A., Parise, J.B., 1998. Elastic properties of hydrous ringwoodite ( $\gamma$-phase) in $\mathrm{Mg}_{2} \mathrm{SiO}_{4}$. Earth Planet. Sci. Lett. 160, 107-113.

Jackson, J.M., Sinogeikin, S.V., Bass, J.D., 2000. Sound velocities and elastic properties of $\gamma$ $\mathrm{Mg}_{2} \mathrm{SiO}_{4}$ to $873 \mathrm{~K}$ by Brillouin spectroscopy. Am. Mineral. 85, 296-303.

Jacobsen, S.D, 2006. Effect of water on the equation of state of nominally anhydrous minerals. Rev. Min. Geochem. 62, 321-342.

Jacobsen, S.D., Smyth, J.R., Spetzler, H., Holl, C.M., Frost, D.J., 2004. Sound velocities and elastic constants of iron-bearing hydrous ringwoodite. Phys. Earth Planet. Inter. 143, 47-56.

Kiefer, B., Stixrude, L., Wentzcovitch, R.M., 1997. Calculated elastic constants and anisotropy of $\mathrm{Mg}_{2} \mathrm{SiO}_{4}$ spinel at high pressure. Geophys. Res. Lett. 24, 2841-2844.

King, H.E., Finger, L., 1979. Diffracted beam crystal centering and its application to high pressure crystallography. J. Appl. Crystallogr. 12, 374-378.

Kohlstedt, D.L., Keppler, H., Rubie, D.C., 1996. Solubility of water in the $\alpha, \beta$, and $\gamma$ phases of $(\mathrm{Mg}, \mathrm{Fe})_{2} \mathrm{SiO}_{4}$. Contrib. Miner. Petrol. 123, 345-357.

Li, B.S., 2003. Compressional and shear wave velocities of ringwoodite gamma- $\mathrm{Mg}_{2} \mathrm{SiO}_{4}$ to 12 GPa. Am. Mineral. 88, 1312-1317.

Liu. Q., Liu. W., Whitaker. M.L., Wang. L.P., Li. B.S., 2008. Compressional and shear wave velocities of $\mathrm{Fe}_{2} \mathrm{SiO}_{4}$ spinel at high pressure and high temperature. High Press. Res. 28, 405-413.

McCammon, C.A., Frost, D.J., Smyth, J.R., Laustsen, H.M.S., Kawamoto, T., Ross, N.L., van Aken, P.A., 2004. Oxidation state of iron in hydrous mantle phases: implications for subduction and mantle oxygen fugacity. Phys. Earth Planet. Inter. 143, 157-169.

Manghnani, M.H., Amulele, G., Smyth, J.R., Holl, C.M., Chen, G., Prakapenka, V., Frost, D.J., 2005. Equation of state of hydrous $\mathrm{Fo}_{90}$ ringwoodite to $45 \mathrm{GPa}$ by synchrotron powder diffraction. Mineral. Mag. 69, 317-323.

Matsui, M., 1999. Computer simulation of the $\mathrm{Mg}_{2} \mathrm{SiO}_{4}$ phases with application to the $410 \mathrm{~km}$ seismic discontinuity. Phys. Earth Planet. Inter. 116, 9-18. 
Matsui, M., Katsura, T., Kuwata, A., Hagiya, K., Tomioka, N., Sugita, M., Yokoshi, S., Nozawa, A., Funakoshi, K., 2006. Equation of state of $\left(\mathrm{Mg}_{0.8} \mathrm{Fe}_{0.2}\right)_{2} \mathrm{SiO}_{4}$ ringwoodite from synchrotron X-ray diffraction up to $20 \mathrm{GPa}$ and $1700 \mathrm{~K}$. Eur. J. Mineral. 18, 523-528.

Meng, Y., Weidner, D.J., Gwanmesia, G.D., Liebermann, R.C., Vaughan, M.T., Wang, Y., Leinenweber, K., Pacalo, R.E., Yeganeh-Haeri, A., Zhao, Y., 1993. In situ high $P-T$ X-ray diffraction studies on three polymorphs $(\alpha, \beta, \gamma)$ of $\mathrm{Mg}_{2} \mathrm{SiO}_{4}$. J. Geophys. Res. 98, 22199-22207.

Nestola, F., Curetti, N., Benna, P., Ivaldi, G., Angel, R.J., Bruno, E., 2008. Compressibility and high-pressure behavior of $\mathrm{Ab}_{63} \mathrm{Or}_{27} \mathrm{An}_{10}$ anorthoclase. Can. Mineral. 46, 1443-1454.

Nestola, F., Angel, R.J., Zhao, J., Garrido, C.J., Sánchez-Vizcaíno, V.L., Capitani, G., Mellini, M., 2010. Antigorite equation of state and anomalous softening at $6 \mathrm{GPa}$ : an in-situ single-crystal X-ray diffraction study. Contrib. Miner. Petrol. doi: 10.1007/s00410-009-0463-9.

Ralph, R.L., Finger, L.W., 1982. A computer program for refinement crystal orientation matrix and lattice constants from diffractometer data with lattice symmetry constrains. J. Appl. Crystall. 15, 537-539.

Ridgen, S.M., Jackson, I., 1991. Elasticity of germanate and silicate spinels at high-pressure. J. Geophys. Res. 96, 9999-10006.

Sinogeikin, S.V., Katsura, T., Bass, J.D., 1998. Sound velocities and elastic properties of Fe-bearing wadsleyite and ringwoodite. J. Geophys. Res. 103, 20819-20825.

Sinogeikin, S.V., Bass, J.D., Katsura, T., 2003. Single-crystal elasticity of ringwoodite to high pressures and high temperatures: implications for $520 \mathrm{~km}$ seismic discontinuity Phys. Earth Planet. Inter. 136, 41-66.

Sinogeikin, S.V., Bass, J.D., Kavner, A., Jeanloz, R., 1997. Elasticity of natural majorite and ringwoodite from the Catherwood meteorite. Geophys. Res. Lett. 24, 3265-3268.

Smyth, J.R., 2006. Hydrogen in high pressure silicate and oxide mineral structures. Rev. Min. Geochem. 62, 85-115.

Smyth, J.R., Holl, C.M., Frost, D.J., Jacobsen, S.D., 2004. High pressure crystal chemistry of hydrous ringwoodite and water in the Earth's interior. Phys. Earth Planet. Inter. 143, 271-278.

Smyth, J.R., Holl, C.M., Frost, D.J., Jacobsen, S.D., Langenhorst, F., McCammon, C.A., 2003. Structural systematic of hydrous ringwoodite and water in Earth's interior. Am. Mineral. 88, 14021407.

Taran, M.N., Koch-Müller, M., Wirth, R., Abs-Wurmbach, I., Rhede, D., Greshake, A., 2009. Spectroscopic studies of synthetic and natural ringwoodite, $\gamma$ - $(\mathrm{Mg}, \mathrm{Fe})_{2} \mathrm{SiO}_{4}$. Phys. Chem. Miner. $36,217-232$.

Wang, J.Y., Sinogeikin. S.V., Inoue, T., Bass, J.D., 2003. Elastic properties of hydrous ringwoodite. Am. Mineral. 88, 1608-1611.

Weidner, D.J., Sawamoto, H., Sasaki, S., Kumazawa, M., 1984. Single-crystal elastic properties of the spinel phase of $\mathrm{Mg}_{2} \mathrm{SiO}_{4}$. J. Geophys. Res. 89, 7852-7860. 


\section{Figure captions}

Figure 1. Evolution of the unit-cell volume as a function of pressure for the spinel studied in this work.

Figure 2. $F_{\mathrm{E}}-f_{\mathrm{E}}$ plot (see the text) for the sample of $\gamma-\mathrm{Fe}_{2} \mathrm{SiO}_{4}$ investigated in this work. The solid line represents the weighted fit of the experimental data.

Figure 3. Confidence ellipse for $\Delta=2.3$ ( $\Delta$ indicating the level confidence, e.g. $\Delta=2.3$ is for a confidence level of $68.3 \%$, the equivalent $1 \sigma$ for a normal distribution of a single variable, see for more details Angel 2000) for the sample of $\gamma$ - $\mathrm{Fe}_{2} \mathrm{SiO}_{4}$ studied in this work.

Figure 4. Evolution of bulk modulus $K_{\mathrm{T} 0}$ as a function of pressure for $\gamma-\mathrm{Fe}_{2} \mathrm{SiO}_{4}$ here studied.

Figure 5. Bulk sound velocity as a function of pressure for different compositions along the Fo-Fa join: $\mathrm{Fo}_{0} \mathrm{Fa}_{100}$ (this study), $\mathrm{Fo}_{50} \mathrm{Fa}_{50}$ and $\mathrm{Fo}_{62} \mathrm{Fa}_{38}$ (Ganskow et al. 2010), $\mathrm{Fo}_{100} \mathrm{Fa}_{0}$ (Hazen 1993 and Sinogeikin et al. 1998). 
Table 1.

\begin{tabular}{|c|c|c|c|}
\hline$P(\mathbf{G P a})$ & $V\left(\AA^{3}\right)$ & \multicolumn{2}{|c|}{ BM3-EoS coefficients } \\
\hline $0.00010(1)$ & $559.38(7)$ & $\mathrm{V}_{0}\left(\AA^{3}\right)$ & $559.44(6)$ \\
\hline $2.060(9)$ & $553.55(4)$ & $K_{\mathrm{T} 0}(\mathrm{GPa})$ & $187.3(1.7)$ \\
\hline $2.740(10)$ & $551.62(4)$ & $K^{\prime}$ & $5.5(4)$ \\
\hline $3.713(13)$ & $548.98(6)$ & $\beta\left(\mathrm{GPa}^{-1}\right)$ & -0.00534 \\
\hline $5.290(14)$ & $544.92(4)$ & ${ }^{\#} \chi^{2}$ & 0.96 \\
\hline $7.914(17)$ & $538.52(4)$ & ${ }^{\$} \Delta P_{\max }(\mathrm{GPa})$ & 0.038 \\
\hline $10.214(12)$ & $533.38(4)$ & & \\
\hline$* 8.857(12)$ & $536.28(5)$ & & \\
\hline$* 6.342(15)$ & $542.34(4)$ & & \\
\hline$* 4.322(10)$ & $547.41(4)$ & & \\
\hline \multicolumn{4}{|c|}{$\begin{array}{l}\text { Notes: *data measured during decompression. " Weighted value (see } \\
\text { Angel 2000). }{ }^{\$} \text { Difference between the observed and refined } \\
\text { pressure. }\end{array}$} \\
\hline
\end{tabular}


FIGURE 1

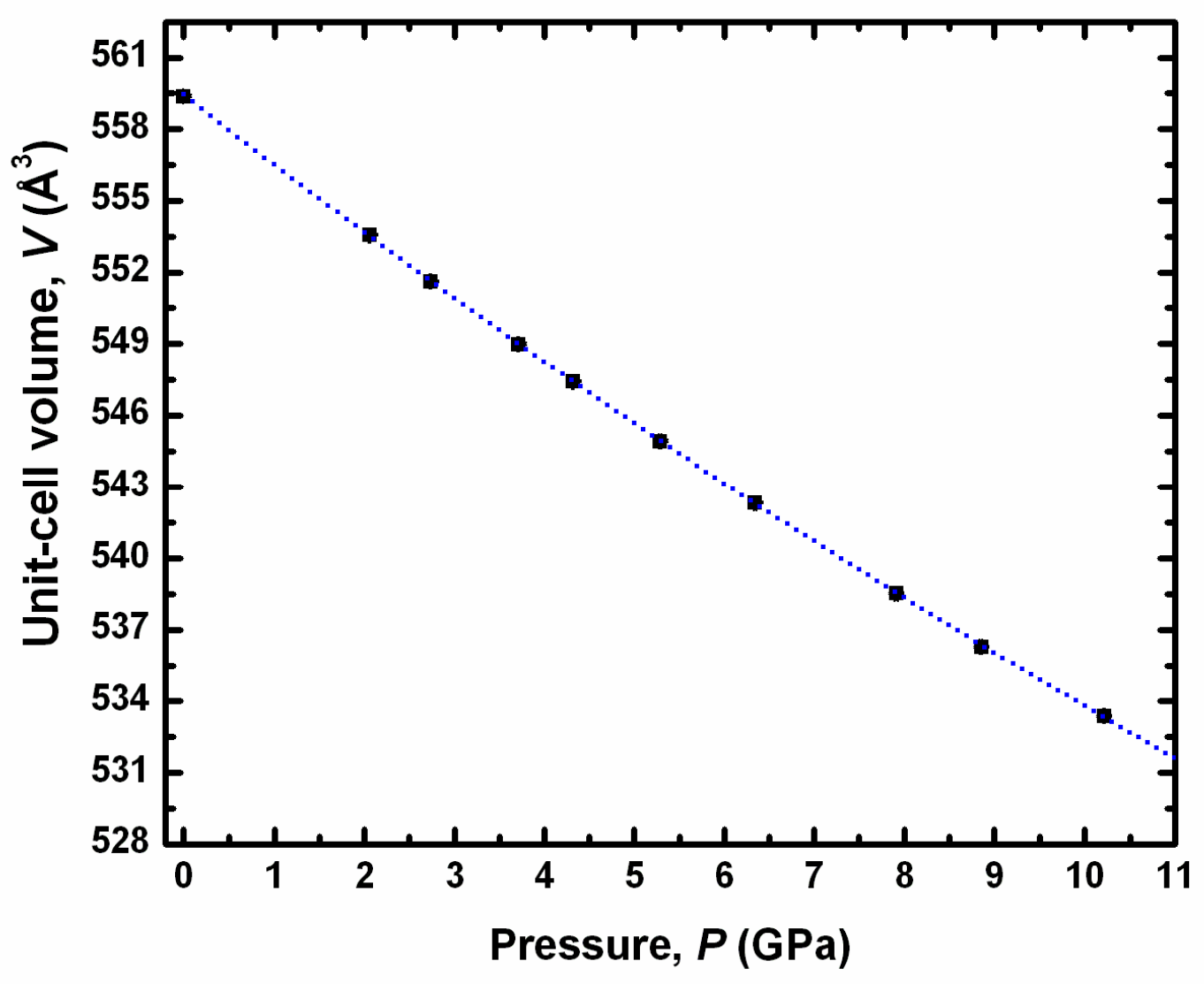


FIGURE 2

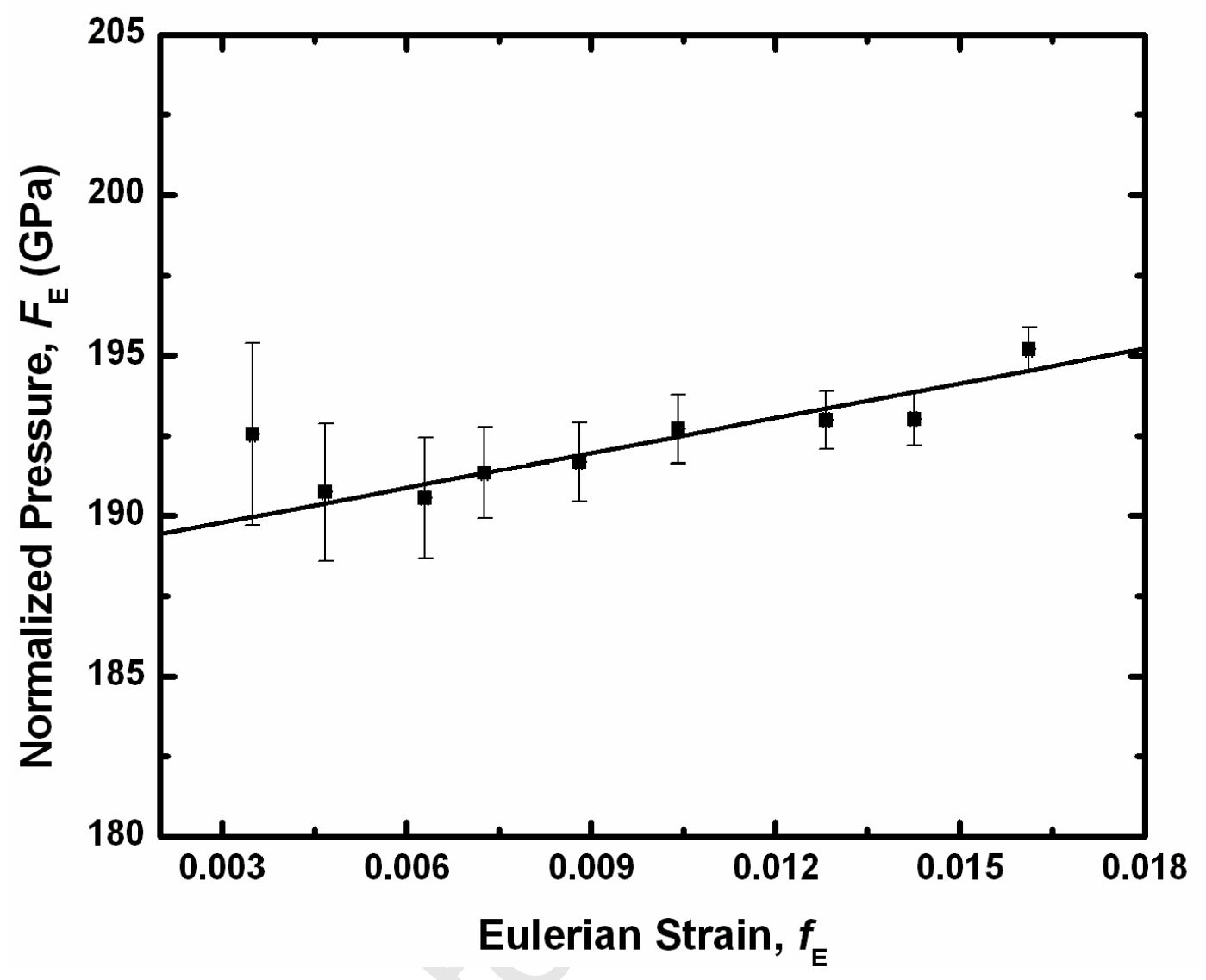


FIGURE 3

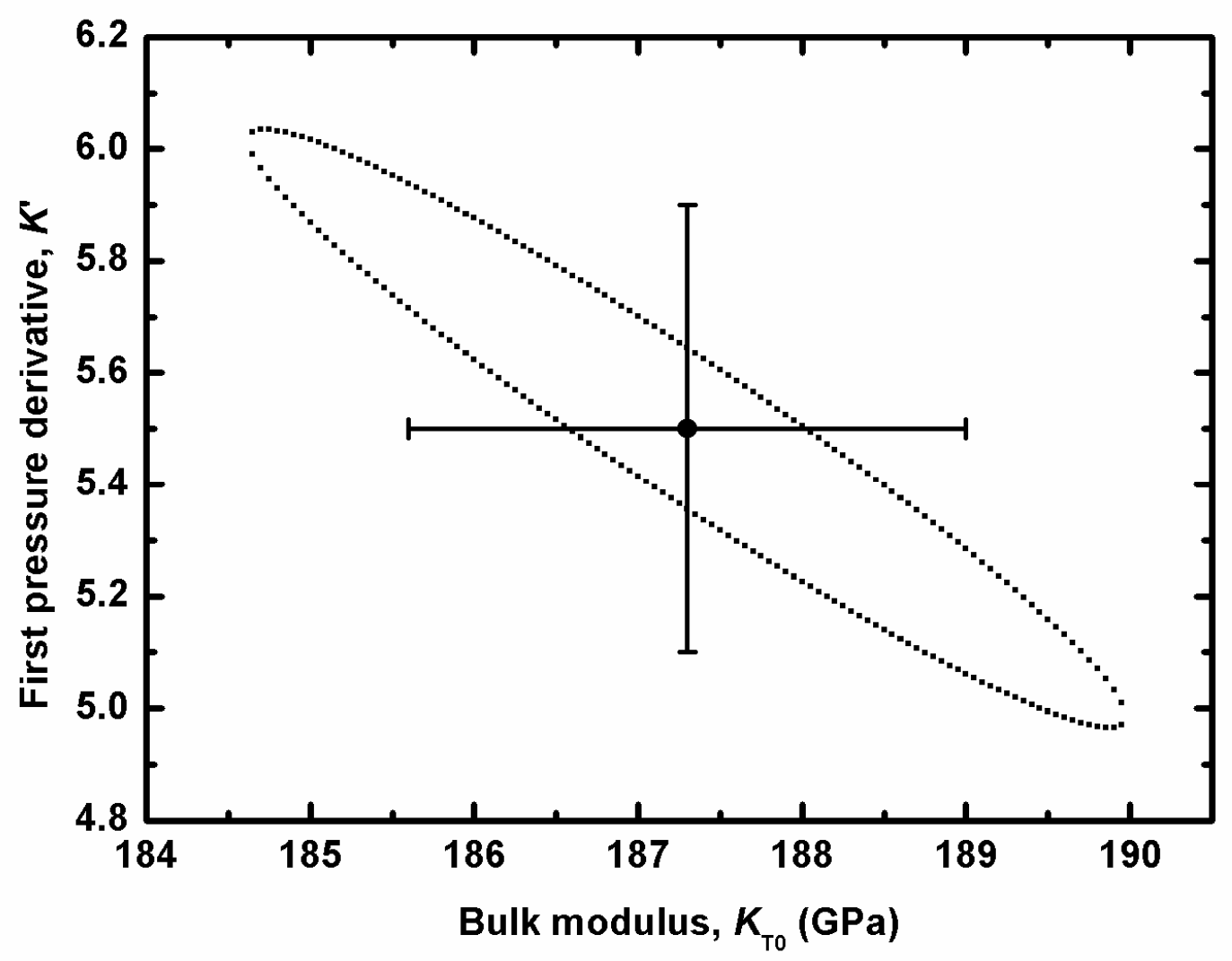


FIGURE 4

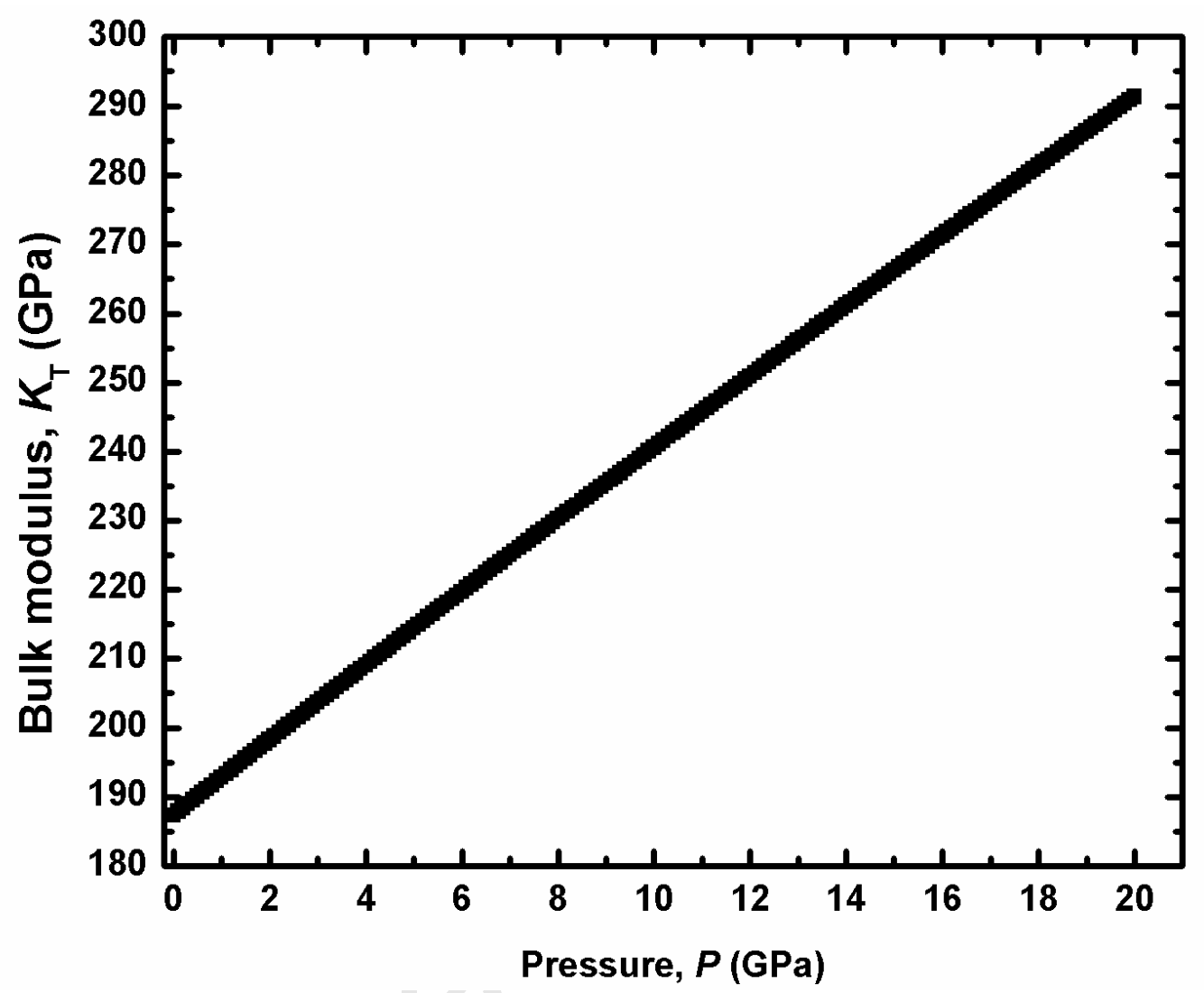


FIGURE 5

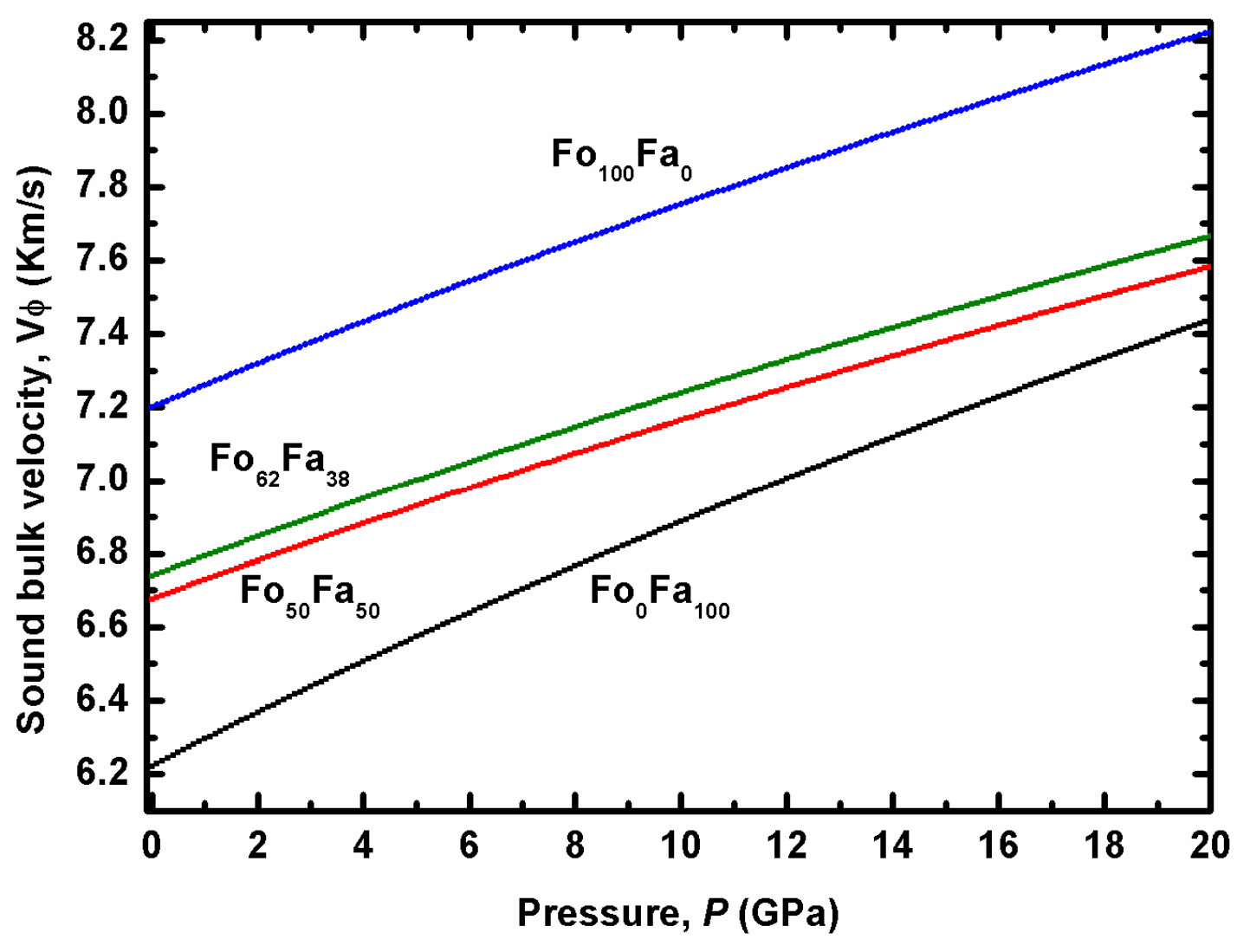

